\title{
Kadar insulin-like growth factor 1, ghrelin ASI, dan peningkatan berat badan bayi pada ibu menyusui obesitas dan normal
}

Levels of insulin-like growth factor-1, ghrelin breast milk and baby weight gain on breastfeeding mother obesity and normal

\author{
Desriati Sinaga ${ }^{1}$, Eny Yantri $^{2}$, Yusrawati ${ }^{3}$ \\ ${ }^{1}$ Program Studi Pascasarjana Ilmu Kebidanan, Fakultas Kedokteran Universitas Andalas, Padang \\ ${ }^{2}$ Bagian Ilmu Kesehatan Anak, Fakultas Kedokteran Universitas Andalas / Rumah Sakit Umum Pusat Dr. M. Djamil, Padang \\ ${ }^{3}$ Bagian Obstetri dan Ginekologi Fetomaternal, Fakultas Kedokteran Universitas Andalas / Rumah Sakit Umum Pusat Dr. M. Djamil, Padang
}

\begin{abstract}
Background: Obesity is one of the factors that trigger the incidence of non-communicable diseases and increase morbidity rates in mothers and infants. Ghrelin hormone in breast milk serves to stimulate appetite in infants as well as release factors for growth hormone (GH). Insulin-like growth factor 1 (IGF-1) hormone in breast milk plays a role in increasing the length of bone and muscle mass of infants and mediators of $G H$ work. Obesity can affect baby's weight gain, ghrelin and IGF-1 hormone levels in breast milk. Objective: Analyzes the association of IGF-1 and ghrelin levels of breast milk with baby's weight gain between obese and normal mothers. Method: Observational study with cross sectional design on 40 breastfeeding mothers and their infants in the work area of Andalas Health Center, Ikur Koto Health Center and Puskesmas Lubuk Buaya Padang City with consecutive sampling technique from August to November 2017. The examination of IGF-1 and ghrelin levels was conducted at the University's Biomedical Laboratory Andalas with ELISA method. Weight gain is obtained from first month infant weight loss with infant birth weight. Data analysis used independent t-test and Pearson test. Results: There was a difference in IGF-1 levels in breast milk $(p=0.00)$ between obese and normal mothers. There was no difference in ghrelin levels of breast milk $(p=0.90)$ between obese and normal mothers. There was a difference in weight gain between obese and normal mothers $(p=0.02)$. There was no significant association between IGF-1 and ghrelin levels of breast milk with an increase baby weight gain between obese and normal mothers. Conclusion: There was no significant association between IGF-1 and ghrelin levels of breast milk with an increase baby weight gain between obese and normal mothers.
\end{abstract}

KEY WORDS: breast milk; ghrelin; IGF-1; infant weight gain; obesity

\begin{abstract}
ABSTRAK
Latar belakang: Obesitas merupakan salah satu faktor pencetus kejadian penyakit tidak menular serta meningkatkan angka morbiditas pada ibu dan bayi. Hormon ghrelin dalam ASI berperan untuk merangsang nafsu makan pada bayi serta faktor rilis untuk growth hormone (GH). Hormon insulin-like growth factor-1 (IGF-1) dalam ASI berperan dalam peningkatan panjang tulang dan massa otot bayi serta mediator kerja GH. Obesitas dapat memengaruhi peningkatan berat badan bayi serta kadar hormon ghrelin dan IGF-1 dalam ASI. Tujuan: Penelitian ini bertujuan untuk menganalisis hubungan kadar IGF-1 dan ghrelin ASI dengan peningkatan berat badan antara ibu obesitas dan normal. Metode: Penelitian observasional dengan rancangan cross sectional terhadap 40 ibu menyusui dan bayinya di wilayah kerja Puskesmas Andalas, Puskesmas Ikur Koto, dan Puskesmas Lubuk Buaya Kota Padang dengan teknik consecutive sampling dari bulan Agustus sampai November 2017. Pemeriksaan kadar IGF-1 dan ghrelin dilakukan di Laboratorium Biomedik Universitas Andalas dengan metode ELISA. Peningkatan berat badan diperoleh dari pengurangan berat badan bayi usia 1 bulan dengan berat badan lahir bayi. Analisis data menggunakan independent t-test dan uji Pearson. Hasil: Ada perbedaan kadar IGF-1 dalam ASI ( $\mathrm{p}=0,00)$ antara ibu obesitas dan normal. Tidak ada perbedaan kadar ghrelin ASI $(\mathrm{p}=0,90)$ antara ibu obesitas dan normal. Terdapat perbedaan peningkatan berat badan bayi antara ibu obesitas dan normal $(\mathrm{p}=0,023)$. Tidak terdapat hubungan yang signifikan kadar IGF-1 dan ghrelin ASI dengan peningkatan berat badan bayi antara ibu obesitas dan normal. Simpulan: Tidak terdapat hubungan yang signifikan antara kadar IGF-1 dan ghrelin ASI dengan peningkatan berat badan bayi antara ibu obesitas dan normal.
\end{abstract}

KATA KUNCI: ASI; ghrelin; IGF-1; peningkatan berat badan bayi; obesitas

Korespondensi: Desriati Sinaga, Program Studi Pascasarjana Ilmu Kebidanan, Fakultas Kedokteran Universitas Andalas, Jl. Perintis Kemerdekaan No. 94 Padang, 25127, Indonesia, Telp.081260889519,e-mail: sinagadesri9@gmail.com 


\section{PENDAHULUAN}

Obesitas merupakan salah satu masalah kesehatan penting dan sudah menjadi masalah kesehatan dunia. Lebih dari 1,9 milyar penduduk usia lebih dari 18 tahun mengalami kelebihan berat badan dan 600 juta diantaranya menderita obesitas serta $15 \%$ terjadi pada wanita dengan kecenderungan peningkatan angka obesitas lebih besar pada wanita $(1,2)$. Prevalensi obesitas di Indonesia pada tahun 2013 sebesar 32,9\% pada wanita usia lebih dari 18 tahun sedangkan di Kota Padang mencapai 39,7\% (3,4).

Obesitas disebabkan oleh pemasukan jumlah makanan yang lebih besar dibandingkan pemakaian oleh tubuh sebagai energi sehingga terjadi kelebihan jumlah jaringan adiposa di dalam tubuh (5). Makanan berlebihan, baik lemak, karbohidrat maupun protein, kemudian disimpan hampir seluruhnya sebagai lemak di jaringan adiposa. Apabila seseorang bertambah berat badannya, maka ukuran sel lemak akan bertambah besar dan jumlahnya bertambah banyak yang mengakibatkan obesitas (6).

Air susu ibu (ASI) merupakan faktor penting untuk mendukung inisiasi dan pertumbuhan komposisi bayi setelah lahir. ASI memberikan nilai nutrisi yang lengkap yaitu komponen energi, nutrisi, dan bioaktif yang secara langsung berpengaruh terhadap pertumbuhan bayi (7). Selain itu, ASI juga mengandung banyak hormon yang berperan untuk metabolisme dan pertumbuhan diantaranya hormon ghrelin dan insulin-like growth factor-1 (IGF-1), semua komponen tersebut akan ditansfer pada bayi ketika menyusu (8-10).

Hormon ghrelin disekresi dari lambung dan berfungsi membawa sinyal lapar dari perifer ke susunan saraf pusat dan merangsang nafsu makan. Hormon ini juga berperan dalam mengatur pelepasan growth hormone (GH) dan homeostasis energi $(11,12)$. Konsentrasi hormon ghrelin rendah pada populasi obesitas sementara pasien dengan anoreksia nervosa memiliki peningkatan kadar serum ghrelin yang signifikan, yang kembali ke normal jika penyakitnya sudah sembuh dan berat badannya dipulihkan (6). Menurut Ganong, kadar ghrelin pada obesitas pada umumnya rendah (13), sementara menurut penelitian Sato menunjukkan penurunan regulasi ghrelin pada orang dengan obesitas (14). Hormon ghrelin yang rendah dalam ASI akan menurunkan nafsu makan pada bayi, hal ini akan terkait dengan penurunan asupan nutrisi dan memengaruhi peningkatan berat badan.

Sementara itu, IGF-1 merupakan hormon yang diproduksi oleh hati serta jaringan lainnya sebagai respon terhadap stimulasi dari $\mathrm{GH}$ yang berfungsi untuk memengaruhi pertumbuhan dan perkembangan tulang serta otot rangka (11). Efek GH terhadap pertumbuhan bergantung pada interaksi antara hormon pertumbuhan dan IGF-1 (15). Hormon IGF-1 berperan dalam regulasi pertumbuhan bayi postnatal dari akhir masa bayi dan seterusnya $(6,11)$. Hormon IGF-1 pada ibu obesitas mengalami peningkatan karena insulin memiliki efek penghambat yang unik terhadap sekresi GH di luar dari pengaruh insulin-like growth factor-1 receptor (IGF-IR) (16). Hormon IGF-1 akan bekerja maksimal dengan bantuan hormon GH dan kadar IGF-1 yang tinggi tidak bisa mengoptimalkan pertumbuhan tulang dan massa otot bayi sehingga akan berpengaruh terhadap peningkatan berat badan bayi $(17,18)$. Penelitian sebelumnya oleh Ode et al yang bertujuan menyelidiki hubungan antara indeks massa tubuh (IMT) ibu sebelum hamil terhadap pertumbuhan bayi awal dan komposisi tubuh, menemukan hasil bahwa kelebihan berat badan ibu atau obesitas berkaitan dengan perlambatan dini pertumbuhan linier dan pertambahan jaringan adiposa (19). Dengan demikian, tujuan penelitian ini adalah untuk mengetahui hubungan antara hormon IGF-1 dan ghrelin dalam ASI dengan peningkatan berat badan bayi antara ibu obesitas dan normal.

\section{BAHAN DAN METODE}

Jenis penelitian observasional dengan menggunakan rancangan penelitian cross sectional. Penelitian dilakukan di wilayah kerja Pukesmas Andalas, Ikur Koto, dan Lubuk Buaya Padang. Pemeriksaan ELISA untuk hormon IGF-1 dan ghrelin dalam ASI dilakukan di Laboratorium Biomedik Fakultas Kedokteran Universitas Andalas. Penelitian ini telah melewati uji kaji etik dari Komite Etik Fakultas Kedokteran Universitas Andalas Padang dengan nomor surat 021/KEP/FK/2017. Sebelum dilakukan pengambilan sampel ASI, peneliti telah memberikan penjelasan dan meminta persetujuan ibu sebagai responden dalam penelitian ini. 
Teknik pengambilan sampel secara consecutive sampling dan subjek yang diambil memenuhi kriteria inklusi yaitu melahirkan normal; tunggal dan aterm; menyusui secara eksklusif sampai 1 bulan; tidak menderita penyakit diabetes melitus; tidak merokok; memiliki riyawat obesitas sebelum hamil untuk kelompok 1 dan berat badan normal sebelum hamil untuk kelompok 2. Kriteria eksklusi adalah bayinya sakit, meninggal, dan bayi diberikan susu atau makanan tambahan lainnya. Besar sampel dalam penelitian ini adalah sebanyak 40 orang ibu menyusui beserta bayinya yang dikumpulkan mulai Agustus-November 2017.

Sampel minimal pada penelitian ini adalah 20 sampel untuk setiap kelompok (obesitas dan normal). Sebanyak 50 orang ibu menyusui obesitas dan normal yang memenuhi kriteria awal bersedia untuk diambil sampel ASI-nya, ditimbang berat badan bayinya setelah lahir, dan ditimbang kembali setelah 1 bulan (30 hari). Setelah 1 bulan, sebanyak 5 orang dikeluarkan dari subjek penelitian karena tidak bisa dihubungi, bayinya sakit dan meninggal sebelum 1 bulan, dan bayi diberikan susu tambahan. Sebanyak 45 ibu yang diambil sampel ASI, sampel akhir yang diperiksa di laboratorium adalah sebanyak 40 sampel ASI karena ada 5 sampel ASI yang rusak.

Variabel yang diteliti yaitu: 1) IGF-1 dalam ASI adalah kadar hormon IGF-1 yang terdapat di dalam ASI. Alat ukur yang digunakan adalah Human IGF-1 Kit (Bioassay Technology Laboratory) dengan satuan $\mathrm{ng} / \mathrm{ml}$; 2) Ghrelin dalam ASI adalah kadar ghrelin yang terdapat di dalam ASI. Alat ukur yang digunakan adalah Human GHRL Kit (Bioassay Technology Laboratory) dengan satuan $\mathrm{ng} / \mathrm{ml}$; 3) Ibu menyusui dengan riwayat obesitas sebelum hamil (IMT prahamil $\geq 30 \mathrm{~kg} / \mathrm{m}^{2}$ ) dan ibu menyusui dengan riwayat berat badan normal sebelum hamil (IMT prahamil 18,5-24,9 kg/m²) dengan data riwayat status gizi ibu diperoleh dari rekam medis buku periksa kehamilan; 4) Peningkatan berat badan bayi adalah peningkatan berat badan bayi sampai usia 1 bulan. Berat badan bayi ditimbang segera setelah bayi lahir dan setelah bayi berusia 1 bulan (30 hari). Berat badan bayi ditimbang dengan menggunakan timbangan digital merk Laica yang sudah ditera dan penimbangan dilakukan oleh peneliti. Peningkatan berat badan bayi dihitung dengan mengurangkan berat badan setelah satu bulan dengan berat badan saat lahir, hasilnya dibagi berat lahir dikali $100 \%$.

Bahan penelitian ini adalah sampel ASI yang diambil sebanyak $3 \mathrm{ml}$ dengan cara diperah atau dengan bantuan pompa ASI tergantung kemauan ibu. Sampel ASI yang sudah diambil kemudian dimasukkan ke dalam microtube dan dibawa ke Laboratorium Biomedik Universitas Andalas Padang. Sampel ASI disentrifuse dengan kecepatan 3000 rpm sebelum disimpan dalam suhu $-20^{\circ} \mathrm{C}$ sampai seluruh sampel terpenuhi. Pemeriksaan kadar IGF-1 dan ghrelin dilakukan oleh petugas Laboratorium Biomedik dengan metode ELISA.

Normalitas data diuji dengan metode Saphiro-wilk kemudian uji perbedaan pada sebaran data yang normal dianalisis menggunakan uji $t$ independen sedangkan uji Mann-Withney untuk sebaran data yang tidak normal. Uji korelasi Pearson digunakan untuk menilai hubungan kadar IGF-1 dan ghrelin ASI dengan peningkatan berat badan bayi.

\section{HASIL}

Jumlah subjek penelitian ini sebesar $40 \mathrm{ibu}$ menyusui dan bayinya yang telah memenuhi kriteria inklusi. Sebagian besar ibu menyusui dengan IMT prahamil normal berada dalam rentang usia 21-30 tahun $(60 \%)$, berpendidikan akhir SMU $(90 \%)$, dan bekerja sebagai ibu rumah tangga (50\%). Sementara itu, ibu menyusui dengan IMT prahamil obesitas sebagian besar berusia 31-40 tahun (65\%), pendidikan SMU (80\%), dan bekerja sebagai ibu rumah tangga (85\%).

Tabel 1 menunjukkan adanya perbedaan rerata kadar IGF-1 dalam ASI antara ibu obesitas dan normal $(\mathrm{p}=0,00)$; tidak terdapat perbedaan kadar ghrelin dalam ASI antara ibu obesitas dan normal $(\mathrm{p}=0,906)$; tidak terdapat perbedaan berat lahir bayi antara ibu obesitas dan normal $(p=0,068)$; tidak terdapat berbedaan berat bayi 1 bulan dari ibu obesitas dan normal $(\mathrm{p}=0,364)$; dan terdapat perbedaan peningkatan berat badan bayi dari ibu obesitas dan normal $(\mathrm{p}=0,023)$.

Tabel 2 menunjukkan bahwa terdapat hubungan negatif yang signifikan antara IMT dengan peningkatan 
Tabel 1. Analisis perbedaan variabel penelitian

\begin{tabular}{lccc}
\hline \multirow{2}{*}{\multicolumn{1}{c}{ Variabel }} & \multicolumn{2}{c}{ Status gizi ibu } & \multirow{2}{*}{ p } \\
\cline { 2 - 3 } & Normal (n=20) & Obesitas (n=20) & \\
\cline { 2 - 3 } & Rerata \pm SD & Rerata \pm SD & \\
\hline IGF-1 dalam ASI (ng/ml) & $2,47 \pm 2,07$ & $17,18 \pm 10,80$ & $<0,001$ \\
Ghrelin dalam ASI (ng/ml) & $0,80 \pm 0,21$ & $0,79 \pm 0,26$ & 0,906 \\
Berat lahir bayi (gram) & $3.258 \pm 323,70$ & $3.439 \pm 281,49$ & 0,068 \\
Berat bayi 1 bulan (gram) & $4.321,5 \pm 490,46$ & $4.201 \pm 320,79$ & 0,364 \\
Peningkatan berat badan bayi selama 1 bulan $(\%)$ & $32,95 \pm 14,43$ & $22,73 \pm 12,73$ & 0,023 \\
\hline
\end{tabular}

Tabel 2. Analisis bivariat hubungan status IMT ibu, kadar IGF-1, dan ghrelin ASI dengan peningkatan berat badan bayi

\begin{tabular}{lcc}
\hline \multirow{2}{*}{ Variabel } & \multicolumn{2}{c}{ Peningkatan berat badan bayi (\%) } \\
\cline { 2 - 3 } & $\mathbf{r}$ & $\mathbf{p}$ \\
\hline IMT ibu & $-0,317$ & 0,046 \\
IGF-1 & $-0,310$ & 0,510 \\
Ghrelin & 0,064 & 0,693 \\
\hline
\end{tabular}

berat badan bayi ( $r=-0,317 ; \mathrm{p}=0,046)$. Namun, tidak terdapat hubungan yang signifikan antara kadar IGF-1 dalam ASI dengan peningkatan berat badan bayi ( $\mathrm{r}=-$ 0,310; $\mathrm{p}=0,510)$. Demikian juga dengan kadar ghrelin dalam ASI dengan peningkatan berat badan bayi $(r=0,064 ; p=0,693)$.

\section{BAHASAN}

Hasil analisis menunjukkan adanya hubungan negatif yang signifikan antara status IMT ibu menyusui dengan persentase peningkatan berat badan bayi. Artinya, terdapat perbedaan persentase peningkatan berat badan bayi yaitu bayi dari ibu obesitas memiliki peningkatan berat badan yang lebih sedikit. Hal ini menunjukkan bahwa ibu menyusui yang memiliki riwayat obesitas sebelum hamil maka peningkatan berat badan bayinya cenderung lebih sedikit dibandingkan dengan ibu dengan berat badan normal sebelum hamil. Menurut penelitian Ode, bayi dari ibu overweight dan obesitas mengalami penambahan berat badan, panjang badan, dan massa lemak yang lebih sedikit. Penelitian tersebut menyimpulkan bahwa kelebihan berat badan ibu/obesitas dikaitkan dengan perlambatan dini pertumbuhan linier dan akrisi jaringan adiposa bayi (19).

Lebih lanjut, hasil penelitian ini menunjukkan adanya perbedaan kadar IGF-1 dalam ASI antara ibu obesitas dan normal dan tampak bahwa kadar IGF1 dalam ASI ibu obesitas lebih tinggi. Namun, hasil analisis menunjukkan tidak adanya hubungan signifikan dengan peningkatan berat badan bayi. Kelebihan gizi dan hiperinsulinemia kronis pada obesitas yang diakibatkan oleh insulin dapat mengubah respons pertumbuhan produksi IGF-1 dan penekanan produksi insulin-like growth factor-binding proteins (IGFBPs) di hati sehingga dapat menghambat bioaktivitas IGF-1 (16).

Insulin memiliki efek penghambat yang unik terhadap sekresi GH. Sel insulin menghambat GH diluar kerja dari IGF-IR. Dengan menghambat GH di hipofisis, akan meningkatkan responsif $\mathrm{GH}$ di hati dan menekan sekresi IGF-BP dan peningkatan GH-binding protein sehingga peningkatan ekspresi reseptor GH dapat menyebabkan kurangnya penekanan kadar IGF-1 $(5,17)$. Konsentrasi IGF-1 bebas lebih tinggi pada orang yang obesitas (6), sementara menurut Garten et al obesitas dikaitkan dengan peningkatan respon IGF-1 terhadap GH (20).

Kadar IGF-1 dalam ASI pada ibu dengan bayi obesitas menunjukkan kadar yang lebih tinggi dibandingkan dengan ibu dari bayi normal (12). Menurut penelitian Kon et al (2014) bahwa ASI yang dikonsumsi oleh bayi yang memiliki kenaikan berat badan tinggi (>1.000 gram) cenderung mengandung kadar IGF-1 yang lebih tinggi daripada yang dikonsumsi oleh bayi dengan kenaikan berat badan yang rendah $(<500$ gram $)$ selama 3 bulan menyusui (21). Kadar IGF-1 dalam ASI mengalami peningkatan konsentrasi seiring bertambahnya usia bayi. Penelitian ini hanya menghubungkan kadar IGF-1 dengan peningkatan berat badan bayi tanpa memperhatikan stimulasi dari GH, hal ini mungkin dapat menjelaskan tidak adanya hubungan yang bermakna antara kadar IGF-1 dengan peningkatan berat badan bayi karena 
fungsi IGF-1 akan lebih optimal apabila ada stimulasi dari hormon GH. Selain itu, IGF-1 bukan merupakan faktor utama penentu peningkatan berat badan. Faktor lain yang memengaruhi berat badan bayi meliputi nutrisi pada bayi, status sosial ekonomi, dan status kesehatan bayi.

Hasil analisis penelitian ini juga menunjukkan bahwa tidak adanya perbedaan kadar ghrelin dalam ASI antara ibu obesitas dan normal. Kadar ghrelin berkorelasi negatif dengan IMT pada manusia secara fisiologis maupun patologis. Kadar ghrelin berkorelasi negatif dengan IMT pada manusia secara fisiologis yaitu kadar ghrelin dalam darah berkurang setelah makan dan meningkat selama puasa (22). Pada kondisi patologis, konsentrasi ghrelin dalam plasma rendah pada populasi obesitas sementara pasien dengan anoreksia nervosa memiliki peningkatan kadar serum ghrelin yang signifikan, yang kembali ke normal bila penyakitnya sudah sembuh dan berat badannya dipulihkan (23). Studi terbaru juga menyebutkan bahwa ada keterkaitan antara obesitas dengan kadar ghrelin di dalam tubuh. Keterkaitan ini diperantarai oleh leptin $(13,22)$. Pada subjek obesitas, leptin gagal untuk memberikan efek normal sehingga leptin eksogen tidak dapat mengurangi adipositas secara signifikan. Kondisi ini akan menyebabkan resistensi leptin (24). Leptin yang terlalu tinggi dalam darah mengakibatkan umpan balik yang tidak menguntungkan sehingga ghrelin juga akan tetap tinggi. Normalisasi keseimbangan regulasi ghrelin dan leptin akan terjadi seiring dengan penurunan massa lemak ibu (25).

Hasil penelitian ini tidak menemukan hubungan yang signifikan antara kadar ghrelin dalam ASI dengan peningkatan berat badan bayi. Penelitian Cesur melaporkan bahwa kadar ghrelin dalam ASI berhubungan dengan berat badan bayi sampai bulan ke-empat dan kadar ghrelin aktif memiliki korelasi positif dengan peningkatan berat badan bayi hingga bulan ke-empat (26). Penelitian ini hanya mengukur peningkatan berat badan bayi sampai usia bayi 1 bulan (30 hari) sehingga persentase peningkatan berat badan bayi belum signifikan.

Selain hormon IGF-1 dan ghrelin, kandungan makronutrien dan mikronutrien dalam ASI lainnya juga memengaruhi berat badan bayi, seperti karbohidrat, protein, lemak, vitamin, dan hormon lainnya. Semua zat gizi ini saling terkait dalam mengoptimalkan pertumbuhan dan perkembangan bayi. Pada usia 0 sampai 6 bulan, pertumbuhan bayi terutama pertambahan berat badan dipengaruhi oleh salah satunya durasi menyusui, komposisi ASI, pola tidur, ibu perokok, dan faktor internal tubuh bayi seperti hormonal, sistem pencernaan, dan penyakit. Prevalensi kelebihan berat badan meningkat seiring dengan peningkatan berat badan lahir dan sebaliknya akan menurun dengan semakin lamanya bayi mendapat ASI $(27,28)$.

Pemberian ASI selalu dianjurkan kepada bayi, karena ASI memiliki komponen makronutrien, mikronutrien, vitamin, antibodi, dan hormonal yang kompleks yang dapat mencegah terjadinya obesitas dikemudian hari (29). Durasi dan frekuensi ibu dalam menyusui bayinya merupakan faktor penting dalam pertumbuhan bayi termasuk peningkatan berat badan bayi (30). Bayi yang mendapatkan ASI secara optimal akan mengalami pertumbuhan yang optimal $(31,32)$. Penelitian ini tidak melakukan observasi durasi dan frekuensi menyusui bayi sehingga mungkin dapat mempengaruhi hasil penelitian.

\section{SIMPULAN DAN SARAN}

Rerata persentase peningkatan berat badan bayi dari ibu obesitas lebih sedikit. Tidak terdapat hubungan yang signifikan kadar IGF-1 dan ghrelin ASI dengan peningkatan berat badan bayi antara ibu menyusui obesitas dan normal. Dianjurkan kepada masyarakat agar mempersiapkan berat badan ideal atau IMT normal sebelum merencanakan kehamilannya sehingga diharapkan gangguan kesehatan akibat obesitas selama kehamilan, melahirkan, dan menyusui dapat dicegah. Dianjurkan kepada ibu menyusui khususnya ibu obesitas agar tidak memberikan susu formula atau tambahan lain meskipun penambahan berat badan bayinya lebih sedikit. Perlu diteliti lebih lanjut hubungan hormon leptin dan insulin atau GH terhadap metabolisme hormon IGF-1 dan ghrelin.

\section{Pernyataan konflik kepentingan}

Tidak ada konflik kepentingan dalam penelitian ini. 


\section{RUJUKAN}

1. Ogden CL, Carrol MD, Fryar CD, Fiegal KM. Prevalence of obesity among adults and youth: United Stated, 2011-2014. NCHS Data Brief. 2015;(219):1-8.

2. Kementerian Kesehatan Republik Indonesia. Riset kesehatan dasar (2013). Jakarta: Kemenkes RI; 2013.

3. SDKI. Survey Demografi dan Kesehatan Indonesia 2012. Jakarta: Kemenkes RI; 2013.

4. Dinas Kesehatan Kota Padang. Profil kesehatan Kota Padang. Padang: Dinas Kesehatan Kota Padang; 2016.

5. Greenstein B, Wood DF. At a glance: sistem endokrin. Jakarta: Erlangga; 2010.

6. Guyton AC, Hall JE. Buku ajar fisiologi kedokteran. Edisi 11. Jakarta: EGC; 2008.

7. Barasi ME. At a glance ilmu gizi. Jakarta: Erlangga; 2007.

8. Ballard O, Morrow AL. Human milk compotition: nutriens and bioactive factors. Pediatr Clin North Am. 2013;60(1):4974. doi: 10.1016/j.pcl.2012.10.002.

9. Ayidin S, Ayidin S, Ozkan Y, Kumru S. Ghrelin is present in human clostrum, transitional and mature milk. Peptides. 2006;27(4):878-82.

10. Savino F, Fissore MF, Liguori S, Oggero R. Can hormones contained in mothers' milk account for the beneficial effect of breast-feeding on obesity in children?. Clin Endocrinol (Oxf). 2009;71(6):757-65. doi: 10.1111/j.13652265.2009.03585.x.

11. Jameson JL, Groot LJ. Ednocrinology adult and pediatric. Philadelphia: Saunders Elsevier; 2010.

12. Tritos NA, Kokkotou, EG. The physiology and potential clinical application of ghrelin, a novel peptide hormone. Mayo Clin Proc. 2006;81(5):653-60.

13. Ganong WF. Buku ajar fisiologi kedokteran. Jakarta: EGC; 2008.

14. Sato T, Ida T, Nakamura Y, Shiimura Y, Kangawa K, Kojima M. Physiological roles of ghrelin on obesity. Obes Res Clin Pract. 2014;8(5):e405-13. doi: 10.1016/j.orcp.2013.10.002.

15. Garwood CJ, Ratcliffe LE, Morgan SV, Simpson JE, Owens $\mathrm{H}$, Wharton SB, et al. Insulin and IGF1 signalling pathways in human astrocytes in vitro and in vivo; characterisation, subcellular localisation and modulation of the receptors. Mol Brain. 2015;8:51. doi: 10.1186/s13041-015-0138-6.

16. Alderete TL, Byrd-Williams CE, Toledo-Corral CM, Conti DV, Weigensberg MJ, Goran MI. Relationships between IGF1 and IGFBP-1 and adiposity in obese African-American and Latino adolescents. Obesity (Silver Spring). 2011;19(5):9338. doi: 10.1038/oby.2010.211

17. Gardner DG, Shoback D. Greenspan's basic \& clinical endocrinology 9th. New York: Mc Graw Hill Lange; 2011.

18. Garten A, Schuster S, Kiess W. The insulin-like growth factors in adipogenesis and obesity. Endocrinol Metab Clin North Am. 2012;41(2):283-95. doi: 10.1016/j.ecl.2012.04.011.
19. Ode LK, Gray HL, Ramel SE, Georgieff MK, Demerath EW. Decelerated early in infants of overweight and obese mothers. J Pediatr. 2012;161(6):1028-34. doi: 10.1016/j. jpeds.2012.06.001.

20. Garten A, Schuster S, Kiess W. The insulin-like growth factors in adipogenesis and obesity. Endocrinol Metab Clin North Am. 2012;41(2):283-95. doi: 10.1016/j.ecl.2012.04.011.

21. Kon IY, Shilina NM, Gmoshinskaya MV, Ivanushkina TA. The study of breast milk IGF-1, leptin, ghrelin and adiponectin levels as possible reasons of high weight gain in breast-fed infants. Ann Nutr Metab. 2014;65(4):317-23. doi: 10.1159/000367998.

22. Muller TD, Nogueiras R, Andermann MI, Andrews ZB, Anker SD, Tschöp MH, et al. Mini review ghrelin. Molecular Metabolism. 2015;4(6):437-60. doi: 10.1016/j. molmet.2015.03.005.

23. Yin X, Li Y, Xu G, An W, Zhang W. Ghrelin fluctuation, what determines its production? Acta Biochim Biophys Sin (Shanghai). 2009;41(3):188-97. doi: 10.1093/abbs/gmp001.

24. Mlinar B, Marc J, Pfeifer M. Molecular mechanisms of insulin ressitance, obesity and metabolic syndrome. Biochemia Medica. 2006;16(1):8-24.

25. Andreas NJ, Hyde MJ, Gale C, Parkinson JR, Jeffries $\mathrm{S}$, Modi N, et al. Effect of maternal body mass index on hormones in breast milk: a systematic review. PLoS One. 2014;9(12):e115043. doi: 10.1371/journal.pone.0115043.

26. Cesur G, Ozguner F, Yilmaz N, Dundar B. The relationship between ghrelin and adiponectin levels in breast milk and infant serum and growth of infants during early postnatal life. J Physiol Sci. 2012;62(3):185-90. doi: 10.1007/s12576012-0193-z.

27. Savino S, Liguori SA, Fissore MF, Oggero R, Silvestro L, Miniero R. Serum ghrelin concentration and weight gain in healthy term infants inthe first year of life. J Pediatr Gastroenterol Nutr. 2005;41(5):653-9.

28. Marcdante KJ, Kliegman RM, Jenson HB, Behrman RE. Nelson essentials of pediatrics 6 edition. Philadelphia: Saunders Elsevier; 2011.

29. Erica HA, Cecilia J. Maternal obesity and breastfeeding; a review of the evidence and implications for practice. Clinical Lactation. 2011;2(3):11-6.

30. Marseglia L, Manti S, D'Angelo G, Cuppari C, Salpietro V, Arrigo T, et al. Obesity and breastfeeding: the strength of association. Women Birth. 2015;28(2):81-6. doi: 10.1016/j. wombi.2014.12.007.

31. United Nations International Children's Fund (UNICEF). Breasfeeding advocacy initiative. [series online] 2015 [cited Juni 2017]. Available online: URL: https://www.unicef.org/ nutrition/files/Breastfeeding_Advocacy_Strategy-2015.pdf

32. Marquest RF, Lopez FA, Braga JA. Growth of exclusively breastfed infants in the first 6 months of life. J Pediatr (Rio J). 2004;80(2):99-105. 